\title{
Androgen receptor expression of proliferating basal and luminal cells in adult murine ventral prostate
}

\author{
J Mirosevich, J M Bentel, N Zeps, S L Redmond, M F D'Antuono, \\ and $\mathbf{H}$ J S Dawkins \\ The Bill and Rhonda Wyllie Laboratory, Urological Research Centre, University of Western Australia, Queen Elizabeth II Medical Centre, Nedlands, Perth, \\ Western Australia 6009, Australia \\ (Requests for offprints should be addressed to H Dawkins)
}

\begin{abstract}
Maintenance of the size and differentiated function of the adult prostate is dependent on testicular androgens. In this study, simultaneous androgen receptor (AR) immunohistochemistry and $\left[{ }^{3} \mathrm{H}\right]$ thymidine labelling was used to characterise the proliferating epithelial cells of the murine ventral prostate. Proliferation in the adult prostate was more prevalent in the basal cell population with 1.8\% AR-negative cells labelled with $\left[{ }^{3} \mathrm{H}\right]$ thymidine as compared with $0 \cdot 7 \%$ AR-expressing luminal cells. Three weeks following castration of mice, the atrophied prostate contained rudimentary glands composed of both luminal and basal cells with the proportion of AR-expressing basal cells reduced from 50 to $25 \%$. Administration of testoster-
\end{abstract}

one enanthate to castrated mice induced a recapitulation of the prostate gland that was preceded by up-regulation of AR expression in basal cells to normal adult levels (50\% AR-positive cells) by $12 \mathrm{~h}$ following testosterone injection. Proliferation of AR-positive luminal cells peaked at $48 \mathrm{~h}(22 \cdot 8 \%)$ while proliferation of AR-negative basal cells peaked at $96 \mathrm{~h}(6 \cdot 1 \%)$ following testosterone administration. These results suggest that distinct populations of luminal and basal cells are resistant to castration-induced involution of the prostate but remain responsive to direct or indirect testosterone effects and recapitulate the gland following administration of testosterone.

Journal of Endocrinology (1999) 162, 341-350

\section{Introduction}

Development of both the human and rodent prostate gland is completed during a pubertal growth phase that occurs in response to increasing production of testosterone by the Leydig cells of the testes (Cunha et al. 1987). In order for adult maturation of the prostate gland and development of secondary male characteristics to occur, testosterone must be converted to $5 \alpha$-dihydrotestosterone by the enzyme 5a-reductase (Bruchovsky \& Wilson 1968, Wilson 1984), and the androgen receptor (AR), which mediates androgen activity in androgen target tissues such as prostate, must contribute a minimum level of ligand binding and transcriptional activity (Quigley et al. 1995).

Throughout adult life the prostate retains its dependence on androgens. Under normal physiological levels of testosterone the adult prostate gland remains at a relatively constant size via a steady but slow turnover of epithelial and stromal cells (Berry \& Isaacs 1984, Isaacs 1984). Withdrawal of testicular androgens (e.g. by castration) induces epithelial cell apoptosis and the prostate atrophies to a rudimentary gland. The rapid induction of proliferation and recapitulation of the adult secretory gland that is observed when testosterone is re-administered, and the ability of the prostate to undergo multiple cycles of involution and recapitulation in response to withdrawal and re-administration of testosterone, have indicated the presence of a single or multiple populations of androgen-responsive progenitor cells within the prostatic epithelium.

The glandular epithelium of the prostate is separated by basal lamina from an inter-glandular stroma that consists of smooth muscle cells and fibroblasts (McNeal et al. 1990). In the adult prostate, the glands and ducts are lined by a dual layer of luminal and basal epithelial cells. Basal cells, which can be distinguished morphologically and by their unique profile of cytokeratin expression (Verhagen et al. 1992), form close contact with the underlying basement membrane but not the glandular lumen (Macklin \& Macklin 1963). The basal cell layer has been proposed to contain the prostatic stem cells that give rise to both basal and luminal epithelial cells of the secretory prostate gland, and to recapitulate the adult differentiated prostate gland following testosterone treatment of castrated mice (Isaacs 1987). Basal cells in the rat and human prostate have been reported to be negative for AR expression (Wernert et al. 1988, Masai et al. 1990, Mobbs \& Lin 1990, Ruizeveld de Winter et al. 1990, Zegers et al. 1991) although a single study has identified positive AR immunohistochemical staining in a proportion of basal cells in normal and 
hyperplastic human prostate specimens (Bonkhoff \& Remberger 1993).

The luminal cells of the prostate produce the prostatic secretions including prostate specific antigen in humans and other kallikreins and additional enzymes in rodents and humans (Verhagen et al. 1992, Partin \& Coffey 1998). Luminal cells express AR and extensive apoptosis of these cells is observed following androgen withdrawal (Isaacs et al. 1992). The luminal cells have been reported as the differentiated progeny of basal progenitor cells of the prostate (Isaacs 1987). However, the findings that not all luminal cells die during prostatic involution induced by androgen withdrawal (Sinha et al. 1981, Sinha \& Bentley 1984, English et al. 1987, Evans \& Chandler 1987a) and that luminal cells proliferate rapidly following re-administration of testosterone (Sinha \& Bentley 1984, English et al. 1987, Evans \& Chandler 1987a), have led to an alternative proposal of cellular hierarchies within the prostate. This model ascribes two separate cell lineages within the prostatic epithelium, a basal cell and luminal cell lineage, each with its own subpopulation of stem cells (Evans \& Chandler 1987a,b).

In this study the androgen responsiveness of the ventral prostatic epithelium was evaluated by determination of AR distribution and expression in proliferating cells of the adult differentiated gland, in the rudimentary prostate in castrated mice and in the recapitulating prostate gland in testosterone-treated castrated mice. AR-expressing luminal cells and AR-negative, but not AR-expressing basal cells were observed to proliferate in the ventral prostate of intact and testosterone-treated castrated mice. Although the basal cell compartment was the most highly proliferative in intact mice, luminal cells exhibited a higher proliferation rate in testosterone-treated castrated mice. These findings have demonstrated both direct and indirect activity of testosterone in the adult prostate and a proliferative potential of both luminal and basal cells.

\section{Materials and Methods}

\section{Animals}

Nine-week-old male BALB/c mice weighing 25-35 g (Animal Resource Centre, Perth, Western Australia) were used in this study. Mice were housed under regulated lighting conditions (12 h light:12 h darkness). Food and water were freely available. All animal procedures were carried out according to protocols approved by the University of Western Australia Animal Ethics Committee. Castration of mice was carried out as follows. Mice were anaesthetised by a single i.p. injection of Avertin according to Hogan et al. (1994). The abdominal fat pads with testes were removed via an abdominal incision and the testicular artery and veins sealed by electro-cautery prior to excision of the testes. Twenty-one days following surgery, testosterone was administered to castrated mice as an s.c. depot of testosterone enanthate (3.6 $\mu \mathrm{g} / \mathrm{g}$ body weight; Schering, Alexandria, Australia) diluted in sesame oil. One hour prior to killing, mice were given a single i.p. injection of $\left[{ }^{3} \mathrm{H}\right]$ thymidine (specific activity $24 \mathrm{Ci} / \mathrm{mmol}$, Amersham International,

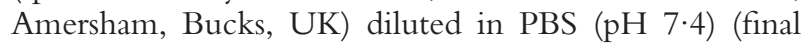
dose $1 \mu \mathrm{Ci} / \mathrm{g}$ body weight). At the time of killing, mice were anaesthetised as described above, blood was removed by heart puncture, they were killed by cervical dislocation and abdominal organs were immediately removed.

\section{Serum testosterone levels}

Blood samples were incubated at $4{ }^{\circ} \mathrm{C}$ for $30 \mathrm{~min}$, centrifuged at $5000 \mathrm{~g}$ for $5 \mathrm{~min}$ and serum removed and stored at $-80{ }^{\circ} \mathrm{C}$. Serum testosterone levels were quantitated using an ACS II Automated Testosterone Analyser (Chiron Diagnostic, Scoresby, Australia).

\section{Preparation of tissues}

Ventral, dorsal and lateral prostates, seminal vesicles, coagulating glands and bladder and a portion of small intestine (to confirm $\left[{ }^{3} \mathrm{H}\right]$ thymidine incorporation) collected at necropsy were washed at room temperature in PBS ( $\mathrm{pH} \mathrm{7.4)} \mathrm{for} 5 \mathrm{~min}$, fixed in 4\% paraformaldehyde (w/v in PBS $\mathrm{pH} 7 \cdot 4$ ) for $1 \mathrm{~h}$ and washed in PBS for 20 min. Specimens were dehydrated through 70, 95 and $100 \%$ ethanol, cleared in chloroform and embedded in paraffin (Tissue-Tek VIP tissue processor, Miles Scientific, Elkhart, IN, USA). Five-micron serial sections were mounted on glass microscope slides coated with 3-aminopropyltriethoxysilane (Sigma Chemical Co., St Louis, MO, USA).

\section{AR immunohistochemistry}

Sections were dewaxed in xylene, rehydrated through alcohol and washed in distilled water. Antigen retrieval was performed in $5 \mathrm{mM}$ EGTA $\mathrm{pH} 8 \cdot 0$ (Sigma) by microwaving slides for $13.5 \mathrm{~min}(9 \times 1.5 \mathrm{~min})$. The sections were incubated in $5 \mathrm{mM}$ EGTA buffer for $5 \mathrm{~min}$ then washed in distilled $\mathrm{H}_{2} \mathrm{O}(2 \times 5 \mathrm{~min})$. Sections were blocked with $1 \% \mathrm{H}_{2} \mathrm{O}_{2}$ in methanol for $15 \mathrm{~min}$, then blocked in 20\% normal horse serum in Tris-buffered saline (TBS) $\mathrm{pH} 7 \cdot 4$ for $30 \mathrm{~min}$. Sections were incubated overnight at $4{ }^{\circ} \mathrm{C}$ in a humidified chamber in rabbit polyclonal AR (N-20) primary antibody (Santa Cruz Biotechnology, CA, USA) diluted 1:100 in TBS containing 1\% BSA. Sections were then incubated for $40 \mathrm{~min}$ with biotinylated swine anti-rabbit secondary antibody (Dako, Sydney, Australia) diluted $1: 200$ in TBS containing 1\% BSA, followed by streptavidin-peroxidase (Silenus Labs, Melbourne, Australia) diluted 1:200 in TBS for $40 \mathrm{~min}$. Between incubations, sections were washed $3 \times 5 \mathrm{~min}$ in PBS containing 0.2\% Tween-20. All incubations were 
carried out at room temperature unless stated otherwise. Visualisation of immunoreactivity was achieved using metal enhanced 3,3'-diaminobenzidine tetrahydrochloride (Pierce, Rockford, IL, USA) for $1.5 \mathrm{~min}$. The sections were washed in warm distilled $\mathrm{H}_{2} \mathrm{O}(2 \times 5 \mathrm{~min})$ then transferred to $70 \%$ ethanol overnight before being dipped in autoradiographic emulsion. For negative control sections, TBS containing 1\% BSA replaced the primary antibody. No immunoreactivity was observed in control sections.

\section{Autoradiography}

Ventral prostate sections and control small intestine sections were coated in Kodak NTB-2 liquid emulsion (Ajax Chemicals, Melbourne, Victoria, Australia) diluted 1:1 with distilled $\mathrm{H}_{2} \mathrm{O}$ and placed in light-proof boxes for 10 days at $4{ }^{\circ} \mathrm{C}$. The slides were developed in Kodak D-19 developer (Ajax) diluted 1:1 with distilled $\mathrm{H}_{2} \mathrm{O}$, for $2.5 \mathrm{~min}$, stopped in $1 \%$ acetic acid for $40 \mathrm{~s}$, fixed in Hypam fixer containing Hypam hardener (40:1) (Ilford, Mt Waverley, Australia) for $4.5 \mathrm{~min}$, and washed in distilled $\mathrm{H}_{2} \mathrm{O}$ for $1 \mathrm{~h}$. All slides were counterstained lightly with haematoxylin, dehydrated through ethanol, cleared in xylene and mounted in Depex (BDH, Kilsyth, Australia).

\section{Western blotting}

Three mice per group were used in this experiment. Ventral prostates removed at necropsy were stored in liquid nitrogen. The human prostate cancer cell lines LNCaP and DU145 were used as positive and negative controls respectively. Tissue samples were powdered in a liquid-nitrogen-chilled Mikro Dismembrator-U (B Braun, Melsungen, Germany), dissolved in sample buffer (0.05 M Tris $\mathrm{pH} 6 \cdot 8,10 \%$ sucrose, $2 \%$ SDS and $4 \%(\mathrm{v} / \mathrm{v})$ $\beta$-mercaptoethanol and $1 \mu \mathrm{g} / \mathrm{ml}$ (each) protease inhibitors (chymostatin, leupeptin, antipain, pepstatin and aprotinin) (Sigma)), heated at $95^{\circ} \mathrm{C}$ for $5 \mathrm{~min}$ and stored at $-20{ }^{\circ} \mathrm{C}$. Samples were electrophoresed in $12 \%$ SDS polyacrylamide gels, then transferred onto polyvinylidene difluoride membranes (Amersham). For AR Western blotting, membranes were blocked with 3\% skim milk powder in TBS for $90 \mathrm{~min}$, rinsed in TBS and incubated for $90 \mathrm{~min}$ in rabbit polyclonal AR (N-20) primary antibody (Santa Cruz Biotechnology) diluted 1:1000 in TBS containing $1 \%$ skim milk powder. Membranes were then incubated for 90 min with sheep anti-rabbit horseradish peroxidaseconjugated secondary antibody (Silenus Labs) diluted 1:4000 in TBS containing $1 \%$ skim milk powder. Between incubations, sections were washed $3 \times 10 \mathrm{~min}$ in TBS containing $0 \cdot 2 \%$ Tween-20. All incubations were carried out at room temperature. Visualisation of immunoreactivity was achieved using enhanced chemiluminescence according to the manufacturer's instructions
(Amersham). A densitometer (Molecular Dynamics, Sunnyvale, CA, USA) was used to scan the developed Western blots. The results were standardised for protein loading against Coomassie Blue-stained gels using Image Quant Software (Molecular Dynamics). Specificity of the AR primary antibody was confirmed by abolition of immunoreactivity of AR antibody that had been preincubated with the peptide used to generate it (Santa Cruz Biotechnology).

\section{Data collection and analysis}

Epithelial cells counts were performed on sections selected by systematic random sampling from the entire ventral prostate of each mouse. These representative sections were counted, moving from top left to bottom right, at $\times 1000$ magnification (oil immersion) using an Olympus BX-40 light microscope. At least 2000 epithelial cells from each animal were counted encompassing the entire crosssection of ducts and glands within ventral prostate sections. Basal and luminal cells were identified histomorphologically using criteria described previously for rodent prostate (English et al. 1987). Immunostaining of ventral prostate sections for high molecular weight cytokeratin (Dako-34ßE12), which labels basal cells (O'Malley et al. 1990), indicated $>95 \%$ concordance in identification of basal cells by histological and high molecular weightimmunohistochemical criteria. Basal and luminal cells were scored according to both their AR expression (positive or negative) and thymidine labelling. Autoradiographic background was low in all slides (<four grains per field) and cells with five or more silver grains over the nucleus were scored as thymidine labelled. All data are expressed as the mean \pm s.E.M. of three or four animals. Group differences were statistically analysed using a Welch modified two-sample $t$-test (to account for unequal variances) and were considered significant at $P<0 \cdot 05$.

\section{Results}

\section{Serum testosterone levels}

In intact adult mice, mean ( \pm S.E.M.) serum testosterone levels were $8.8 \pm 1.6 \mathrm{nmol} / 1$ (Fig. 1). Three weeks following castration, the concentration of testosterone was significantly reduced to $3 \cdot 6 \pm 0 \cdot 1 \mathrm{nmol} / 1 \quad(P<0 \cdot 05)$. Administration of testosterone to castrated mice increased serum testosterone levels to a peak of $48.6 \pm 4.9 \mathrm{nmol} / 1$ at $12 \mathrm{~h}$ (Fig. 1). Serum testosterone levels decreased steadily after $12 \mathrm{~h}$ and were $9 \cdot 2 \pm 1 \cdot 9 \mathrm{nmol} / 1$ at $144 \mathrm{~h}$.

\section{Prostatic histological analysis}

Haematoxylin and eosin staining of paraffin-embedded prostate tissue sections indicated that the ventral prostates 


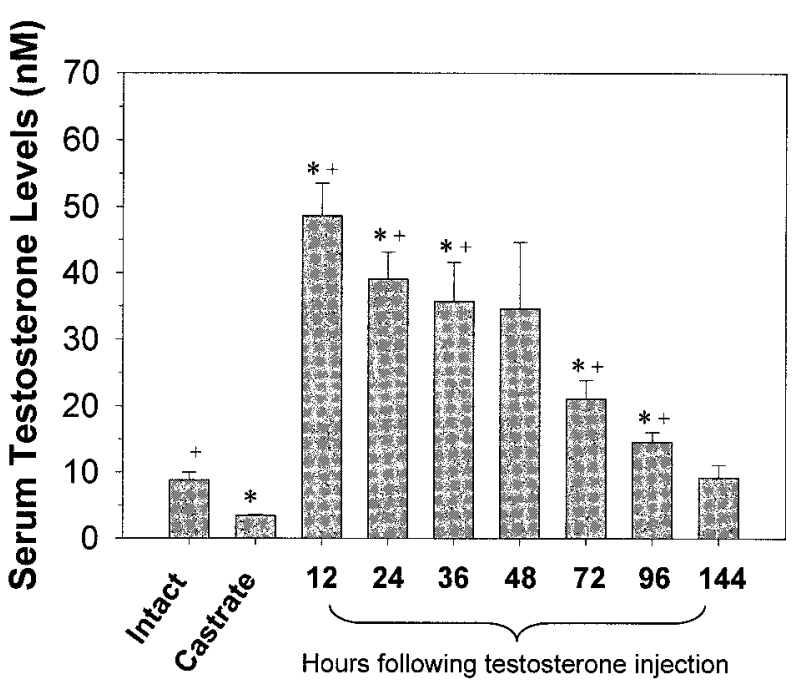

Treatment Groups

Figure 1 Serum testosterone levels in intact mice $(n=4), 3$-week castrated mice $(n=6)$ and castrated mice following testosterone administration ( $n=4$ per timepoint). Results are expressed as means \pm S.E.M. ${ }^{*}=$ Significantly different from intact animals, $P<0 \cdot 05$; $+=$ significantly different from 3 -week castrated mice, $P<0 \cdot 05$.

of intact adult mice consisted of ducts and highly infolded glands separated by stroma (Fig. 2A). Stromal cells were usually spindle shaped and loosely organised around glands and ducts. Glands and ducts were surrounded by basal lamina, which appeared as an eosinophilic membrane separating the epithelial cells from the stroma (Fig. 2A inset). In the ventral prostate, glands contained a single layer of tall columnar luminal cells while ducts were lined with cuboidal luminal cells. Underlying triangular-shaped basal cells which contained very small amounts of cytoplasm were observed adjacent and parallel to the basal lamina (Fig. 2A inset).

Three weeks following castration, ventral prostates consisted of rudimentary glandular structures containing both luminal and basal cells (Fig. 2B). Luminal cells were cuboidal in shape with less cytoplasm than that evident in intact animals, while the basal cells appeared morphologically similar under light microscopy to prostatic basal cells of intact mice (Fig. 2B inset). In comparison with the normal ventral prostates of intact mice, a greater density of stromal cells was evident between rudimentary ventral prostatic glands of castrated animals (Fig. 2B).

Thirty-six hours following administration of testosterone to castrated mice, the cuboidal luminal cells had become tall and regained a columnar epithelial appearance (results not shown). By $48 \mathrm{~h}$ the basal lamina had thinned and appeared similar to that in the ventral prostates of intact mice. At this time, glands began to form epithelial infolds as in intact mice. By $96 \mathrm{~h}$ after testosterone administration, the stroma appeared less dense and more closely resembled intact mouse prostate (results not shown).

\section{AR immunohistochemical analysis}

In intact mice, AR staining was localised exclusively in the nucleus of epithelial and stromal cells (Fig. 2C). Within the ventral prostate, no differences in staining patterns were observed between luminal cells of glands and the ducts. All luminal cells stained positively for AR, while $49 \cdot 2 \pm 0 \cdot 6 \%$ of the basal cells were also positive for AR in both glands and ducts (Fig. 3). Generally, luminal cells showed more intense staining for AR compared with basal cells. AR staining appeared heterogeneous between cells within the same gland or duct with the staining intensities in luminal cells ranging from very strong to moderate and basal cells containing moderate to very weak staining. Nuclear AR staining was also observed in a proportion of stromal cells (results not shown). However, these cells stained more weakly for AR, suggesting that epithelial cells expressed higher levels of AR than stromal cells.

Three weeks following castration, the rudimentary glandular structures contained luminal cells that were all strongly AR positive (Fig. 2D). However, the proportion of AR-positive basal cells had reduced significantly to only $24.5 \pm 0.9 \%(P<0 \cdot 001)$ (Fig. 3).

In ventral prostates of castrated mice treated with testosterone, AR expression in luminal cells remained at $100 \%$. Administration of testosterone to castrated mice resulted in an increase in the number of AR-positive basal cells. The proportion of basal cells staining positively for AR reached normal levels, that is approximately 50\% AR-positive staining at $12 \mathrm{~h}$ (Fig. 3).

\section{Cell counts}

In the ventral prostates of intact mice, the ratio of luminal to basal cells in glands and ducts was approximately 13:1 (Fig. 4). Low levels of proliferation were seen in this group with approximately $0 \cdot 80 \pm 0.03 \%$ of epithelial cells in the ventral prostates labelled with $\left[{ }^{3} \mathrm{H}\right]$ thymidine (Fig. 4). Proliferation was only observed in AR-negative basal or AR-positive luminal cells (Fig. 2C). In intact mice, $1 \cdot 8 \pm 0 \cdot 2 \%$ of basal cells were proliferating. This was approximately two and a half times greater than that observed in the luminal cell layer where $0 \cdot 70 \pm 0 \cdot 02 \%$ of cells were proliferating (Fig. 5).

Three weeks following castration, the ratio of luminal to basal cells in ventral prostates had been reduced to approximately 3:1 (Fig. 4). Castration also resulted in decreased thymidine labelling such that very low levels of proliferation were seen in epithelial cells of these mice $0 \cdot 34 \pm 0 \cdot 03 \%$ (Fig. 4). Only AR-positive luminal cells were labelled (results not shown). 

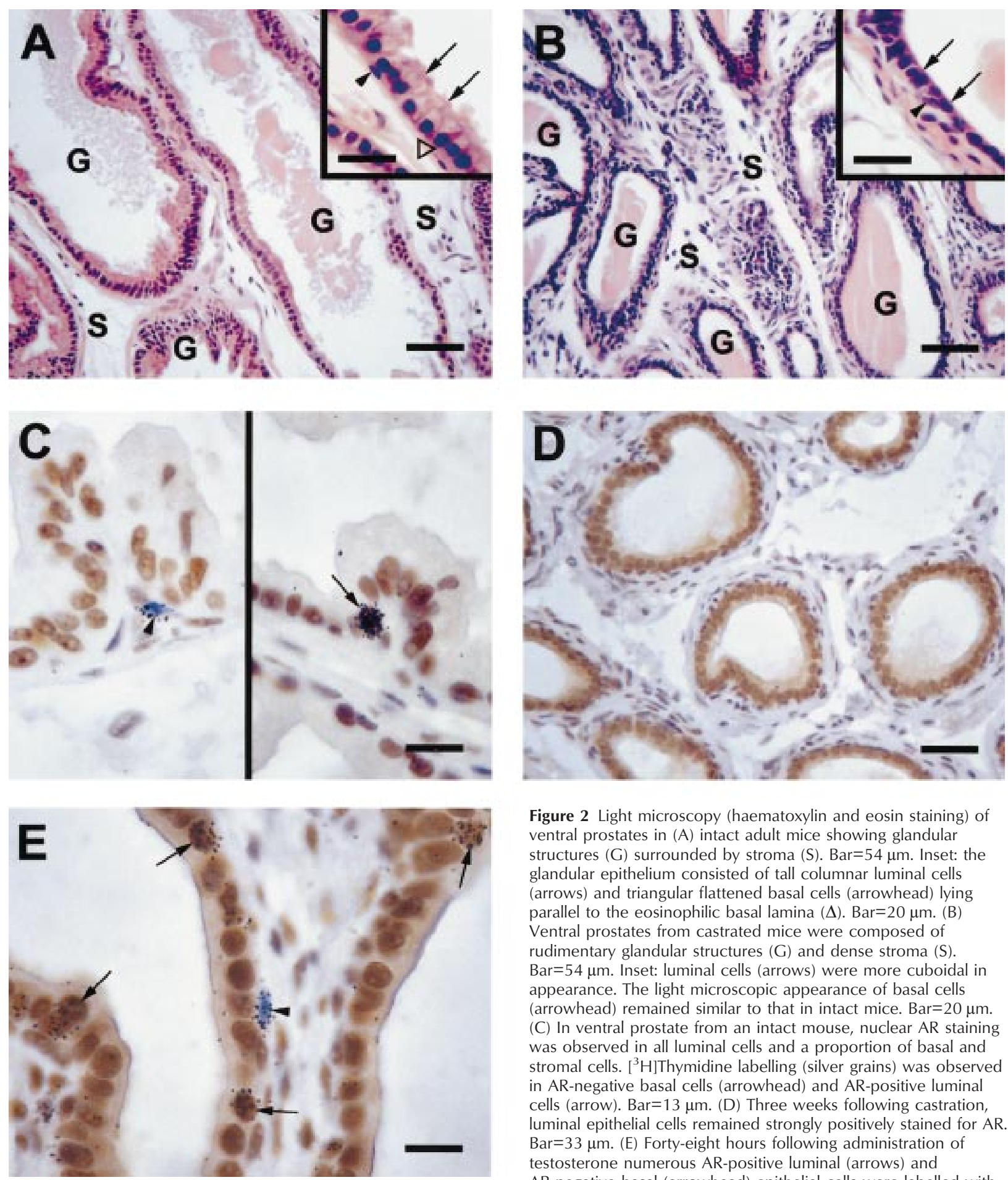

Figure 2 Light microscopy (haematoxylin and eosin staining) of ventral prostates in $(A)$ intact adult mice showing glandular structures (G) surrounded by stroma (S). Bar $=54 \mu \mathrm{m}$. Inset: the glandular epithelium consisted of tall columnar luminal cells (arrows) and triangular flattened basal cells (arrowhead) lying parallel to the eosinophilic basal lamina $(\Delta)$. Bar $=20 \mu \mathrm{m}$. (B) Ventral prostates from castrated mice were composed of rudimentary glandular structures $(\mathrm{G})$ and dense stroma $(\mathrm{S})$. Bar $=54 \mu \mathrm{m}$. Inset: luminal cells (arrows) were more cuboidal in appearance. The light microscopic appearance of basal cells (arrowhead) remained similar to that in intact mice. Bar $=20 \mu \mathrm{m}$. (C) In ventral prostate from an intact mouse, nuclear AR staining was observed in all luminal cells and a proportion of basal and stromal cells. $\left.{ }^{3} \mathrm{H}\right]$ Thymidine labelling (silver grains) was observed in AR-negative basal cells (arrowhead) and AR-positive luminal cells (arrow). Bar $=13 \mu \mathrm{m}$. (D) Three weeks following castration, luminal epithelial cells remained strongly positively stained for AR. Bar $=33 \mu \mathrm{m}$. (E) Forty-eight hours following administration of testosterone numerous AR-positive luminal (arrows) and AR-negative basal (arrowhead) epithelial cells were labelled with $\left[{ }^{3} \mathrm{H}\right]$ thymidine. Bar $=13 \mu \mathrm{m}$. 


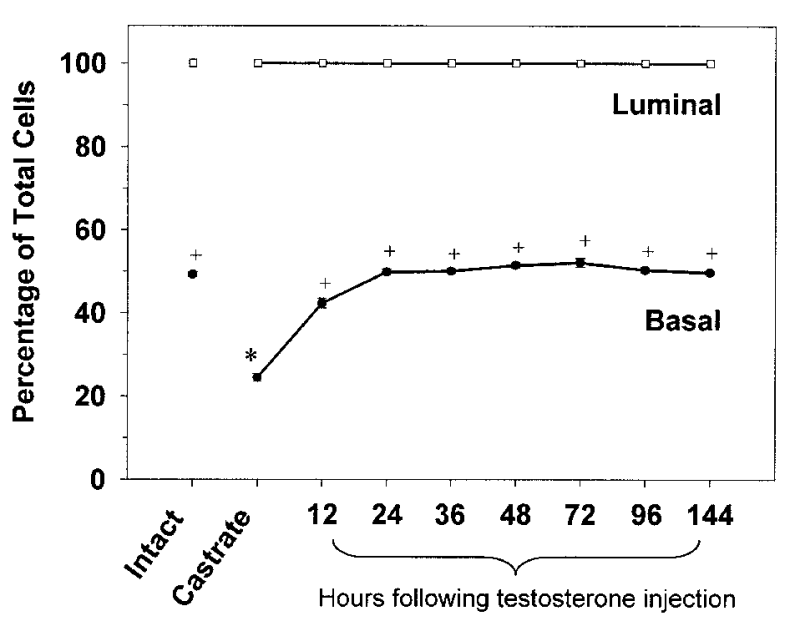

Treatment Groups

Figure 3 AR expression in basal and luminal cells of the mouse ventral prostate. The proportions of basal and luminal cells expressing AR in ventral prostates of intact mice $(n=3)$, 3-week castrated mice $(n=3)$ and testosterone-treated castrated mice $(n=4$ per timepoint) were calculated as a percentage of total basal or luminal cells respectively. Results are expressed as percentage mean \pm S.E.M. * $=$ Significantly different from intact animals, $P<0 \cdot 05$; $+=$ significantly different from 3 -week castrated mice, $P<0 \cdot 05$.

Following treatment of castrated mice with testosterone, the ratio of luminal to basal cells increased to $13: 1$ by $144 \mathrm{~h}$ (Fig. 4). Very few $(0 \cdot 32 \pm 0 \cdot 01 \%)$ labelled cells

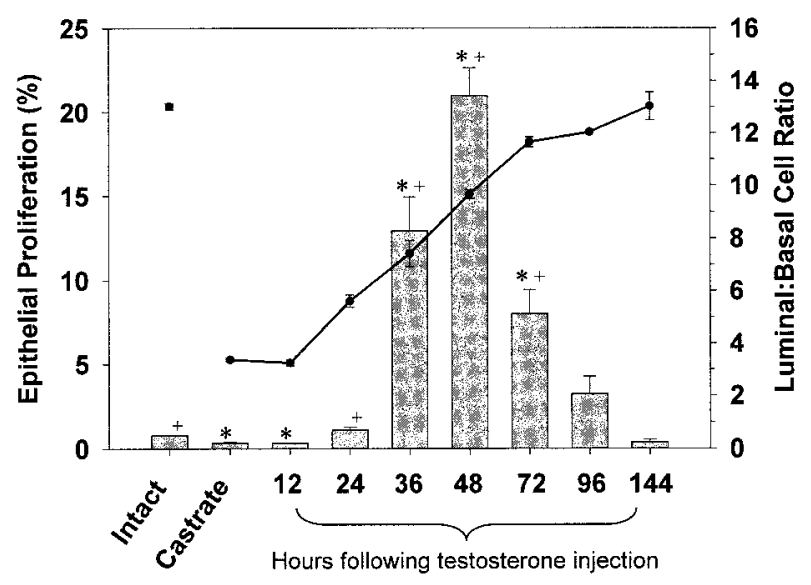

Treatment Groups

Figure 4 Epithelial cell proliferation (bars), as determined by $\left[{ }^{3} \mathrm{H}\right]$ thymidine autoradiography, and expressed as a percentage of total cells in ventral prostates of intact mice $(n=3)$, 3-week castrated mice $(n=3)$ and castrated mice following administration of testosterone ( $n=4$ per timepoint). Results are expressed as means \pm S.E.M. * $=$ Significantly different from intact animals, $P<0.05$; $+=$ significantly different from 3 -week castrated mice, $P<0 \cdot 05$. The luminal to basal cell ratio $(\bullet)$ decreased significantly $(P=0)$ in castrated mice and increased to levels similar to intact mice by $144 \mathrm{~h}$ following testosterone treatment.

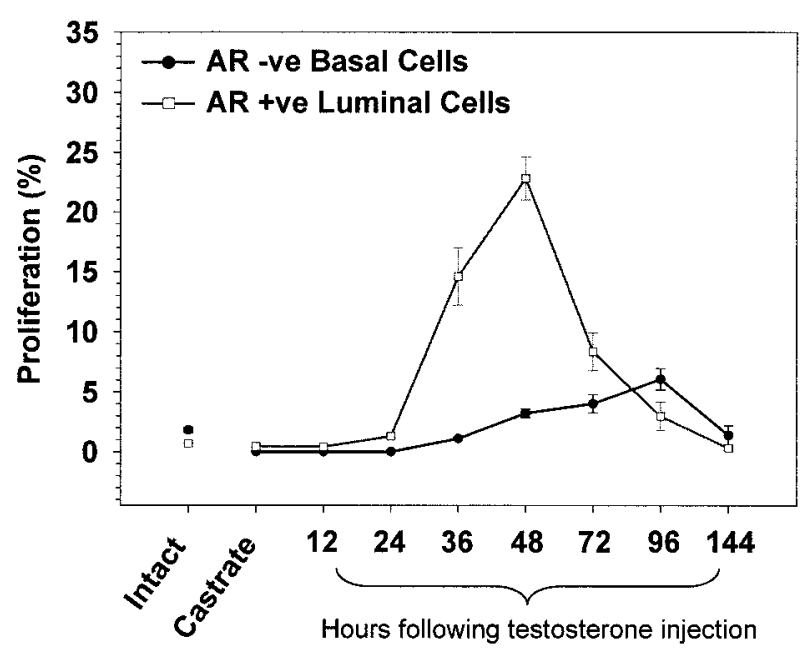

Treatment Groups

Figure 5 Proliferation of basal and luminal cells of the mouse ventral prostate in intact mice $(n=3), 3$-week castrated mice $(n=3)$ and castrated mice following administration of testosterone $(n=4$ per timepoint). AR-negative basal cells and AR-positive luminal cells were the only two cell types that were observed to be labelled with $\left[{ }^{3} \mathrm{H}\right]$ thymidine. Results are expressed as means \pm S.E.M.

were detected $12 \mathrm{~h}$ after administration of testosterone. Epithelial proliferation began to increase in mice $24 \mathrm{~h}$ following testosterone treatment $(1 \cdot 10 \pm 0 \cdot 15 \%)$ and continued increasing to $21 \cdot 0 \pm 1 \cdot 7 \%$ at $48 \mathrm{~h}$. Thereafter, labelling of epithelial cells declined to $0 \cdot 37 \pm 0 \cdot 16 \%$ at $144 \mathrm{~h}$. Similar to intact mice, thymidine labelling was only observed in the AR-negative basal and AR-positive luminal cells (Fig. 2E). In mice treated with testosterone, luminal cell proliferation commenced $24 \mathrm{~h}$ following administration of testosterone (Fig. 5). Proliferation of luminal cells peaked at $22 \cdot 8 \pm 1 \cdot 8 \%$ at $48 \mathrm{~h}$ after testosterone treatment. By $144 \mathrm{~h}$ after testosterone administration, proliferation of luminal cells had reduced to $0 \cdot 30 \pm 0 \cdot 14 \%$. A similar pattern of proliferation was observed in basal cells. Basal cell proliferation commenced $36 \mathrm{~h}$ after administration of testosterone and peaked at $6 \cdot 1 \pm 0.9 \%$ at $96 \mathrm{~h}$ after testosterone treatment. Subsequently, basal cell proliferation had decreased to $1 \cdot 4 \pm 0 \cdot 8 \% 144 \mathrm{~h}$ after administration of testosterone.

\section{Western analysis}

A $110 \mathrm{kDa}$ band corresponding to the AR protein was evident in all ventral prostate tissue samples and in the LNCaP cells. No AR protein bands were detected in extracts of DU145 cells or on membranes incubated with peptide-absorbed AR antibody (results not shown). The linear range of AR detection by Western blotting was determined using increasing amounts of LNCaP cell extracts (Fig. 6). In prostate tissue samples, densitometric 

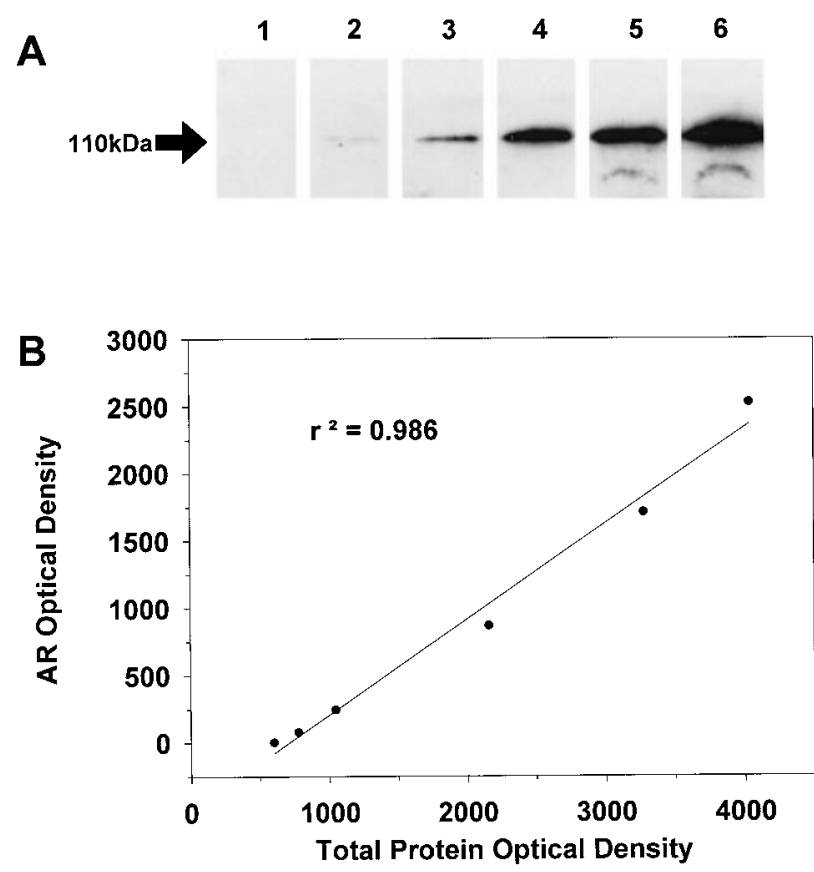

Figure 6 Quantitation of AR protein levels by Western blotting. (A) Western blot analysis for AR protein in total protein extracted from LNCaP cells. Lanes: 1, $0 \mu \mathrm{l} ; 2,1 \mu \mathrm{l} ; 3,2.5 \mu \mathrm{l} ; 4,7.5 \mu \mathrm{l} ; 5,10 \mu \mathrm{l}$; $6,12 \cdot 5 \mu \mathrm{L} \mathrm{LNCaP}$ cell extract. (B) Quantitation of AR protein relative to total protein, as determined by comparative densitometric analysis of AR Western blot and Coomassie Blue-stained polyacrylamide gels respectively.

analysis indicated a 3.5-fold reduction of AR protein levels in ventral prostates from 3-week castrated mice compared with intact mice. Twelve hours following administration of testosterone to castrated mice, ventral prostate AR protein levels increased approximately 17-fold compared with castrated mice (Fig. 7). AR protein levels decreased after $12 \mathrm{~h}$ and by $96 \mathrm{~h}$ were similar to levels observed in intact mice.

\section{Discussion}

The present studies have demonstrated that castration of male adult mice leading to atrophy of the prostate results in decreased AR protein expression in the whole gland, a reduction in the proportion of basal cells expressing AR and no alteration in the proportion of surviving luminal epithelial cells that express AR protein. Following administration of testosterone to the castrated mice, the androgen responsiveness of the prostatic epithelium is characterised by the up-regulation of AR expression in prostatic basal cells and the rapid induction of proliferation of ARexpressing luminal cells and AR-negative basal cells. These findings indicate that populations of cells with progenitor-like potential may reside in both the luminal

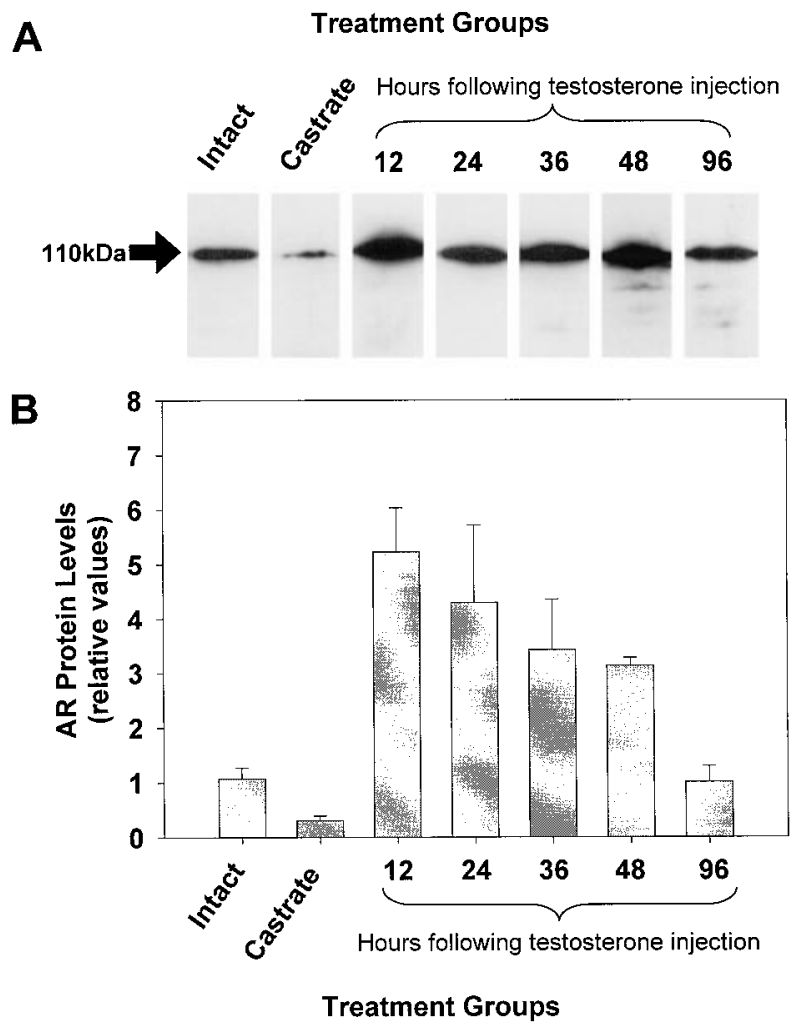

Figure 7 AR protein levels as determined by Western blot analysis. (A) Western blot of AR protein levels in ventral prostates of intact mice, 3-week castrated mice and castrated mice following administration of testosterone. (B) Densitometric quantitation of relative AR protein levels. Results are expressed as means \pm S.E.M. of three animals per group.

and basal cell compartments of the prostatic glands and ducts. While androgen-responsive for proliferation and differentiated (secretory) functions, these cells appear to be androgen-independent for survival.

Involution of the prostate gland following castration is associated with increased programmed cell death of luminal cells resulting in an approximately $80 \%$ loss of prostatic epithelial cells (Coffey et al. 1968, Isaacs et al. 1992). The glandular atrophy is incomplete, however, and histological findings in this and previous studies indicate that rudimentary glandular structures remain even after prolonged periods of castration (Sinha et al. 1981, Evans \& Chandler 1987a). These glandular rudiments consist of both luminal and basal cells, with a decreased relative proportion of luminal:basal cells (3:1 as compared with 13:1 in the intact animal). Although castration results in a significant reduction of serum testosterone levels, a low but detectable level of serum testosterone remains. It is feasible therefore that the rudimentary glandular structures are maintained by residual testosterone levels or that all or a proportion of these cells are androgen-independent for survival. 
The direct actions of androgens in target cells are mediated by the AR (Lubahn et al. 1988). In the prostate, androgens appear to act as an apoptosis inhibitor since androgen withdrawal (i.e. castration) results in rapid induction of apoptosis that leads to atrophy of the gland (Kyprianou \& Isaacs 1988, Isaacs et al. 1992). In the present and in previous studies (Wernert et al. 1988, Masai et al. 1990, Mobbs \& Lin 1990, Ruizeveld de Winter et al. 1990, Prins et al. 1991, Zegers et al. 1991, Bonkhoff \& Remberger 1993), prominent AR expression was evident in the luminal cells of the prostatic glands and it is these cells that undergo apoptosis following castration of rodents and other species (Price \& Williams-Ashman 1961, Brandes 1966, Lesser et al. 1973, Sinha et al. 1981, Isaacs 1984, English et al. 1987, Kyprianou \& Isaacs 1988, Isaacs et al. 1992). Although at 3 weeks following castration of mice, histological evidence of cell death (apoptosis) or cell proliferation was virtually absent in the prostate, almost all of the surviving luminal cells expressed AR at similar immunohistochemical levels to prostatic luminal cells of intact mice. The mechanisms responsible for the apparent apoptosis resistance of these residual AR-expressing luminal cells is currently unknown. Whether these cells represent a single population or contain progenitor cells of the differentiated prostatic secretory cells of the recapitulated adult gland is also unresolved.

In contrast to the luminal cells, immunohistochemical methods detected low levels of AR in 50\% of prostatic basal cells in the intact animal. Previous studies of rat and canine prostate have identified basal cells as AR negative (Prins et al. 1991), findings that suggest species-specific differences in AR distribution in cell types of the prostate or increased sensitivity of AR detection resulting from utilisation of different AR antibodies. Although several previous studies using human prostate tissues have reported AR expression exclusively in the prostatic luminal cells (Wernert et al. 1988, Masai et al. 1990, Mobbs \& Lin 1990, Ruizeveld de Winter et al. 1990, Zegers et al. 1991), AR expression in a proportion of basal cells in normal and hyperplastic human prostate has recently been described in a single report (Bonkhoff \& Remberger 1993). The relationship between ARexpressing and AR-negative basal cells and the functional role of the basal cell population in the adult prostate gland is at present unclear.

In the adult prostate, the basal cell population has been suggested to contain stem cells of the luminal epithelium, to function as a regulator of secretory cell numbers (Isaacs 1987, Bonkhoff \& Remberger 1996) or as a cellular mediator of stromal cell modulation of the luminal cell population (Cunha et al. 1987). Studies in both rat and human prostate have demonstrated that the basal cells do not have a myoepithelial or contractile role in the prostate (Srigley et al. 1990, Prins et al. 1991). Basal cells are not as responsive as luminal cells to androgen withdrawal and their numbers are not believed to alter dramatically following castration (English et al. 1987). In this study, the proportion of AR-expressing basal cells was found to be reduced 3 weeks following castration and to increase to normal levels by $12 \mathrm{~h}$ following testosterone administration. Since this up-regulation of AR expression occurred prior to the testosterone-induced initiation of basal cell proliferation, a common lineage of at least a proportion of the AR-expressing and AR-non-expressing basal cells is suggested. AR-expressing basal cells labelled with $\left[{ }^{3} \mathrm{H}\right]$ thymidine were never observed in intact, castrated or testosterone-treated mice, suggesting that proliferation of these cells does not contribute directly to maintenance or testosterone-induced recapitulation of the gland. Preservation of a consistent proportion of ARexpressing cells in intact mice and the rapid restoration of this ratio following testosterone administration to castrated mice indicate an important role for these cells, potentially in directing the secretory function of the adjacent luminal cells of the gland or as precursors of this luminal cell population.

In addition to maintenance of prostatic glandular size, testicular androgens are required for maintenance of the differentiated function of the prostate gland. In the rodent, these include androgen-induced expression of prostatic enzymes such as the glandular kallikreins and production of prostatic secretions (Cunha et al. 1987, Clements 1994, Partin \& Coffey 1998). Histological features of the prostate in castrated mice, including the more flattened appearance of luminal epithelial cells and the increased density of the periglandular stroma, are similar to those observed in pre-pubescent male mice (Sugimura et al. 1986). These findings, and the previously described absence of expression of prostatic secretory proteins in castrated mice, suggest a loss of differentiation in cells of the prostate following androgen withdrawal. The thickened basement membrane surrounding glands and ducts of castrated mice has been attributed to infolding of the basal lamina around glands that have rapidly decreased in size following castration (Decarvalho \& Line 1996). It is feasible that the basement membrane would equilibrate to a more normal thickness following longer time periods post-castration.

Re-administration of testosterone to castrated mice results in recapitulation of the prostate to its original size and differentiated function. Following injection of testosterone, the histology of the prostate alters and the luminal cells become tall and columnar as in intact mice, and stromal cell density and the thickness of the basement membrane are reduced as the rudimentary glands enlarge. These histological alterations are correlated with the up-regulation of expression of prostatic secretory proteins (Cunha et al. 1987, Clements 1994, Partin \& Coffey 1998) and are similar to the growth and initiation of adult secretory function of the prostate that is observed during pubertal development. Androgen-induced resurrection of the differentiated appearance and function of the prostate in castrated mice occurs concurrently with the 
up-regulation of prostatic $\mathrm{AR}$ and widespread induction of cellular proliferation.

Proliferation of cells of the prostatic epithelium in adult mice was only observed in AR-negative basal cells and AR-expressing luminal cells. These findings suggest direct and indirect effects of androgens on prostatic epithelial cells both during steady-state maintenance of the gland and mediating testosterone-induced recapitulation of the prostate in castrated mice. A low but reproducible level of proliferation was evident in the basal and luminal compartments of intact mice, findings that were consistent with previous reports (Sinha et al. 1981, Sinha \& Bentley 1984). Of interest was the observation that basal cell proliferation was more than double luminal cell proliferation in intact mice. Such findings indicate that a subpopulation of basal cells exhibits a high turnover rate as compared with luminal cells. Alternatively, if as suggested by Isaacs (1987) the basal and luminal cell populations are representative of a single cell lineage with the progenitor cells residing in the basal cell population, a proportion of the intermediate or amplifying cells may be located in the basal cell layer in the adult steady-state gland.

The steady-state proliferation rate in the prostatic epithelium was reduced to virtually undetectable levels at 3 weeks following castration. Although following testosterone administration serum testosterone levels had peaked by $12 \mathrm{~h}$, peak proliferation of prostatic epithelial cells was detected at $48 \mathrm{~h}$, the lag time consistent with previous reports (Lesser \& Bruchovsky 1973) and potentially due to induction of expression of accessory proteins required for S-phase progression. Synthesis of RNA (Butler \& Schade 1958, Liao et al. 1965, Coffey et al. 1968, Katz et al. 1989) and protein (Coffey et al. 1968, Chung \& Coffey 1971a,b), but not DNA, has been demonstrated during this lag phase. While proliferation of luminal cells peaked at $48 \mathrm{~h}$ post testosterone administration, basal cell proliferation peaked at $96 \mathrm{~h}$ after testosterone injection. The longer lag time prior to S-phase progression in basal cells may be due to androgen effects being indirect in this AR-negative cell type and requiring protein synthesis in other cells (luminal and stromal cells) to initiate cell cycle progression.

This study has demonstrated the existence of androgenregulated homeostasis within the adult prostate gland controlling total AR content of the gland, relative proliferation rates of basal and luminal epithelial cells, the relative proportions of AR-expressing and AR-negative basal cells and the basal:luminal cell ratio. These effects are the result of both direct and indirect androgen activity. Populations of AR-positive luminal and AR-positive and ARnegative basal cells are resistant to the androgen depletion caused by castration of mice and are activated in a coordinated manner to recapitulate the gland following androgen administration. Further evaluation of the functional activity of epithelial cell types described in this study will identify cell lineages within the adult prostate gland, their role in differentiated secretory prostatic function and potentially the cell of origin and associated biological processes that lead to dysplasia and formation of prostate cancer.

\section{Acknowledgements}

This research was supported by the Neville Stanley Bursary, the Urological Research Centre, Perth, Western Australia and the Raine Foundation, University of Western Australia.

\section{References}

Berry S \& Isaacs JT 1984 Comparative aspects of prostatic growth and androgen metabolism with aging in the rat versus the dog. Endocrinology 114 511-520.

Bonkhoff H \& Remberger K 1993 Widespread distribution of nuclear androgen receptors in the basal cell layer of the normal and hyperplastic human prostate. Virchows Archiv 422 35-38.

Bonkhoff H \& Remberger K 1996 Differentiation pathways and histogenetic aspects of normal and abnormal prostatic growth: a stem cell model. Prostate 28 98-106.

Brandes D 1966 The fine structure and histochemistry of prostatic glands in relation to sex hormones. International Review of Cytology 20 207-276.

Bruchovsky N \& Wilson JD 1968 The conversion of testosterone to 5-alpha-androstan-17-beta-ol-3-one by rat prostate in vivo and in vitro. Journal of Biological Chemistry 243 2012-2021.

Butler WWS \& Schade AL 1958 The effects of castration and androgen replacement on the nucleic acid composition, metabolism, and enzymatic capacities of the rat ventral prostate. Endocrinology 63 271-279.

Chung LW \& Coffey DS 1971a Biochemical characterization of prostatic nuclei. I. Androgen-induced changes in nuclear proteins. Biochimica et Biophysica Acta 247 570-583.

Chung LW \& Coffey DS $1971 b$ Biochemical characterization of prostatic nuclei. II. Relationship between DNA synthesis and protein synthesis. Biochimica et Biophysica Acta 247 584-596.

Clements JA 1994 The human kallikrein gene family: a diversity of expression and function. Molecular and Cellular Endocrinology 99 C1-C6.

Coffey DS, Shimazaki J \& Williams-Ashman HG 1968 Polymerization of deoxyribonucleotides in relation to androgen-induced prostatic growth. Archives of Biochemistry and Biophysics 124 184-198.

Cunha GR, Donjacour AA, Cooke PS, Mee S, Bigsby RM, Hissing SJ \& Sugimura Y 1987 The endocrinology and developmental biology of the prostate. Endocrine Reviews 8 338-362.

Decarvalho HF \& Line SRP 1996 Basement membrane associated changes in the rat ventral prostate following castration. Cell Biology International 20 809-819.

English HD, Santen RJ \& Isaacs JT 1987 Response of glandular versus basal rat ventral prostatic epithelial cells to androgen withdrawal and replacement. Prostate 11 229-242.

Evans GS \& Chandler JA 1987 a Cell proliferation studies in the rat prostate: II. The effects of castration and androgen-induced regeneration upon basal and secretory cell proliferation. Prostate 11 339-351.

Evans GS \& Chandler JA $1987 b$ Cell proliferation studies in the rat prostate: I. The proliferative role of basal and secretory cells during normal growth. Prostate 10 163-178.

Hogan B, Beddington RSP, Costantini F \& Lacy E 1994 Manipulating the Mouse Embryo: A Laboratory Manual, p 416. New York: Cold Spring Harbor Press. 
Isaacs JT 1984 Antagonistic effect of androgen on prostatic cell death. Prostate 5 545-557.

Isaacs JT 1987 Control of cell proliferation and cell death in the normal and neoplastic prostate: a stem cell model. In Benign Prostatic Hyperplasia, NIH publication \#87-2881, pp 85-94. Eds CH Rodgers, DS Coffey, G Cunha, JT Greyhack, F Hinman Jr \& R Norton. Washington DC: US Department of Health and Human Services.

Isaacs JT, Lundmo PI, Berges R, Martikainen P, Kyprianou N \& English HF 1992 Androgen regulation of programmed death of normal and malignant prostatic cells. Journal of Andrology 13 457-464.

Katz AE, Benson MC, Wise GJ, Olsson CA, Bandyk MG, Sawczuk IS, Tomashefsky P \& Buttyan R 1989 Gene activity during the early phase of androgen-stimulated rat prostate regrowth. Cancer Research 49 5889-5894.

Kyprianou N \& Isaacs JT 1988 Activation of programmed cell death in the rat ventral prostate after castration. Endocrinology 122 552-562.

Lesser B \& Bruchovsky N 1973 The effects of testosterone, $5 \alpha$-dihydrotestosterone and adenosine $3^{\prime}, 5^{\prime}$, monophosphate on cell proliferation and differentiation on rat prostate. Biochimica et Biophysica Acta 308 426-437.

Liao S, Leininger KR, Sagher D \& Barton RW 1965 Rapid effect of testosterone on ribonucleic acid polymerase activity of rat ventral prostate. Endocrinology 77 763-765.

Lubahn D, Joseph DR, Sullivan PM, Willard HF, French FS \& Wilson EM 1988 Cloning of the human androgen receptor complementary DNA and localization to the X chromosome. Science 240 327-330.

Macklin CC \& Macklin MT 1963 The seminal vesicles, prostate and bulbourethral glands. In Special Cytology, pp 1771-1822. Ed. EV Cowdry. New York: McGraw-Hill.

McNeal JE, Villers AA, Redwine EA, Freiha FS \& Stamey TA 1990 Capsular penetration in prostate cancer: significance for natural history and treatment. American Journal of Surgical Pathology 14 240-247.

Masai M, Sumiya H, Akimoto S, Yatani R, Chang C, Liao S \& Shimazaki J 1990 Immunohistochemical study of androgen receptor in benign hyperplastic and cancerous human prostates. Prostate $\mathbf{1 7}$ 293-300.

Mobbs BG \& Lin Y 1990 Immunohistochemical localisation of progesterone receptor in benign and malignant human prostate. Prostate 16 245-251.

O'Malley FP, Grignon DJ \& Shum DT 1990 Usefulness of immunoperoxidase staining with high-molecular-weight cytokeratin in the differential diagnosis of small-acinar lesions of the prostate gland. Virchows Archiv 417 191-196.

Partin AW \& Coffey DS 1998 The molecular biology, endocrinology, and physiology of the prostate and seminal vesicles. In Campbell's Urology, vol 2, pp 1381-1428. Eds PC Walsh, AB Retik, ED Vaughan \& AJ Wein. Philadelphia: Saunders.
Price D \& Williams-Ashman HG 1961 The accessory reproductive glands of mammals. In Sex and Internal Secretions, pp 366-448. Eds WC Young \& GW Corner. Baltimore: Williams and Wilkins.

Prins GS, Birch L \& Greene GL 1991 Androgen receptor localization in different cell types of the adult rat prostate. Endocrinology 129 3187-3199.

Quigley CA, De Bellis A, Marschke KB, el-Awady MK, Wilson EM \& French FS 1995 Androgen receptor defects: historical, clinical, and molecular perspectives. Endocrine Reviews 16 271-321.

Ruizeveld de Winter JA, Trapman J, Brinkmann AO, Boersma WJA, Mulder E, Schroeder FH, Claassen E \& van der Kwast TH 1990 Androgen receptor heterogeneity in human prostatic carcinomas visualised by immunohistochemistry. Journal of Pathology 161 329-332.

Sinha AA \& Bentley MD 1984 The relationship of epithelial cell types in the ventral prostate glands of castrated mice treated with testosterone. Anatomical Record 208 533-544.

Sinha AA, Bentley MD, Pomroy FE \& Jamuar MP 1981 Freezefracture, ultrastructure and autoradiographic analysis of the ventral prostate glands in castrated mice. Cell and Tissue Research $\mathbf{2 1 5}$ 547-561.

Srigley JR, Dardick I, Hartwick RWJ \& Klotz L 1990 Basal epithelial cells of human prostate gland are not myoepithelial cells. American Journal of Pathology 136 957-966.

Sugimura Y, Cuhna GR \& Donjacour AA 1986 Morphogenesis of ductal networks in the mouse prostate. Biology of Reproduction 34 961-971.

Verhagen APM, Ramaaekers FCS, Aalders TW, Schaafsma HE, Debruyne FMJ \& Schalken JA 1992 Colocalisation of basal and luminal cell-type cytokeratins in human prostate cancer. Cancer Research 52 6182-6187.

Wernert N, Gerdes J, Loy V, Seitz G, Scherr O \& Dhom G 1988 Investigations of the estrogen (ER-ICA-test) and the progesterone receptor in the prostate and prostatic carcinoma on immunohistochemical basis. Virchows Archiv 412 387-391.

Wilson JD 1984 The endocrine control of sexual differentiation. Harvey Lectures 79 145-172.

Zegers ND, Claassen E, Neelen C, Mulder E, Van Laar JH, Voorhorst MM, Berrevoets CA, Brinkmann AO, van der Kwast TH, Ruizeveld de Winter JA, Trapman J \& Boersma WJA 1991 Epitope prediction and confirmation for the human androgen receptor: generation of monoclonal antibodies for multi-assay performance following the synthetic peptide strategy. Biochimica et Biophysica Acta 1073 23-32.

Received 28 October 1998

Revised manuscript received 4 February 1999 Accepted 20 April 1999 